Nia Mirandha Septiani \& Wirman/ Pengaruh Pembiayaan Murabahah, Musyarakah, Dan Mudharabah

Terhadap Profitabilitas (Roa) Bank Umum Syariah Di Indonesia

\title{
PENGARUH PEMBIAYAAN MURABAHAH, MUSYARAKAH, DAN MUDHARABAH TERHADAP PROFITABILITAS (ROA) BANK UMUM SYARIAH DI INDONESIA
}

\author{
Nia Mirandha Septiani \\ ${ }^{1,2}$ Universitas Singaperbangsa Karawang \\ 1710631030134@ student.unsika.ac.id ${ }^{1 *}$, \\ Wirman \\ ${ }^{1,2}$ Universitas Singaperbangsa Karawang
}

\begin{abstract}
This study aims to determine the effect of murabahah, musyarakah, and murabahah on the profitability of Islamic commercial banks in Indonesia for the 2015-2019 period. The type of research used is quantitative research with descriptive research methods. The data analysis method used in this research is Multiple Linear Regression Analysis. The results showed that murabahah, musharakah and murabaha simultaneously affect ROA. Murabaha has a partially significant negative effect on ROA while Musharaka and Mudaraba have a partially significant positive effect on ROA.
\end{abstract}

Keywords : murabahah, musharakah, murabaha, ROA.

\section{PENDAHULUAN}

Perkembangan perbankan di Indonesia semakin mengalami pertumbuhan yang pesat sejalan dengan semakin meningkatnya permintaan dan pemikiran masyarakat akan lembaga keuangan terutama Bank. Bank sendiri dibagi 2 jenis, Konvensional dan Syariah, dimana Bank Konvensional ialah Bank yang menjalankan usahanya berupa pemberian jasa dalam laju pembayaran secara konvensional. Sedangkan, dalam UU No 21 tahun 2008, Bank Syariah ialah Bank yang melaksanakan aktivitas bisnisnya dengan didasarkan pada prinsip syariah diatur fatwa MUI.

Menurut (Prasetyo, 2018) perbankan syariah pada kenyataannya terbukti lebih bisa bertahan pada saat krisis sekalipun, meski didasarkan pada prinsip yang berbeda dengan konvensional. Hal ini terbukti dari berkembangnya Bank Syariah di Indonesia yang semakin mengalami pertumbuhan seiring dengan semakin meningkatnya pemikiran masyarakat tentang sistem yang digunakan dalam bank syariah, yaitu tanpa menggunakan bunga (riba). Hal inilah yang menjadikan perbankan syariah mengalami pertumbuhan yang pesat dan dijadikan alternatif menarik bagi kalangan masyarakat sebagai pengguna jasa perbankan. Perkembangan inilah yang memicu semakin banyaknya BUS. Tercatat dari data statistik perbankan syariah pada tahun 2019 ada 14 BUS, angka ini lebih banyak jika dibandingkan dengan tahun 2015 yang berjumlah 12 BUS (sumber: ojk.go.id).

Dapat terlihat dari perkembangan bank syariah yang terus berkembang maju setiap tahunnya, haruslah dilakukan penilaian untuk melihat kondisi pada bank tersebut. Profitabilitas adalah satu dari aspek yang dapat dipergunakan untuk melihat kondisi tersebut. Sama halnya dengan perusahaan nonbank yang beroperasi dengan tujuan menghasilkan keuntungan, bank pun memiliki tujuan akhir untuk mendapat keuntungan. Jadi dapat dikatakan salah satu aspek yang dapat dipergunakan untuk mengukur kinerja suatu bank adalah aspek profitabilitas. Menurut Harahap dalam (Prasetyo, 2018) profitabilitas dapat menggambarkan keberhasilan perusahaan dalam memperoleh keuntungan yang didapat atas kesekuruhan kemampuan serta sumber yang ada. Suatu bank harus bisa menjaga profitabilitasnya agar bank tersebut selalu dapat menjaga keberlangsungan dari usahanya. 
Profitabilitas ini dapat diukur maupun dilihat dari laporan keuangan dengan cara menganalisis rasio profitabilitas yang ada didalam laporan keuangan tersebut, karena rasio profitabilitas tersebut dapat mengukur tingkat keberhasilan serta kemampuan dari bank untuk memperoleh laba. Dengan adanya beberapa jenis dari rasio profitabilitas bank, salah satu rasio yang penulis pilih ialah Return On Assets (ROA). $R O A$ ialah alat untuk menilai keberhasilan manajemen dalam memperoleh laba bersih dari pengelolaan aset (Kasmir, 2015:236). Jika nilai ROA pada bank meningkat, maka akan sejalan dengan peningkatan keuntungan yang akan diperoleh bank, yang kemudian membuat posisi bank semakin baik dalam penggunaan asetnya.

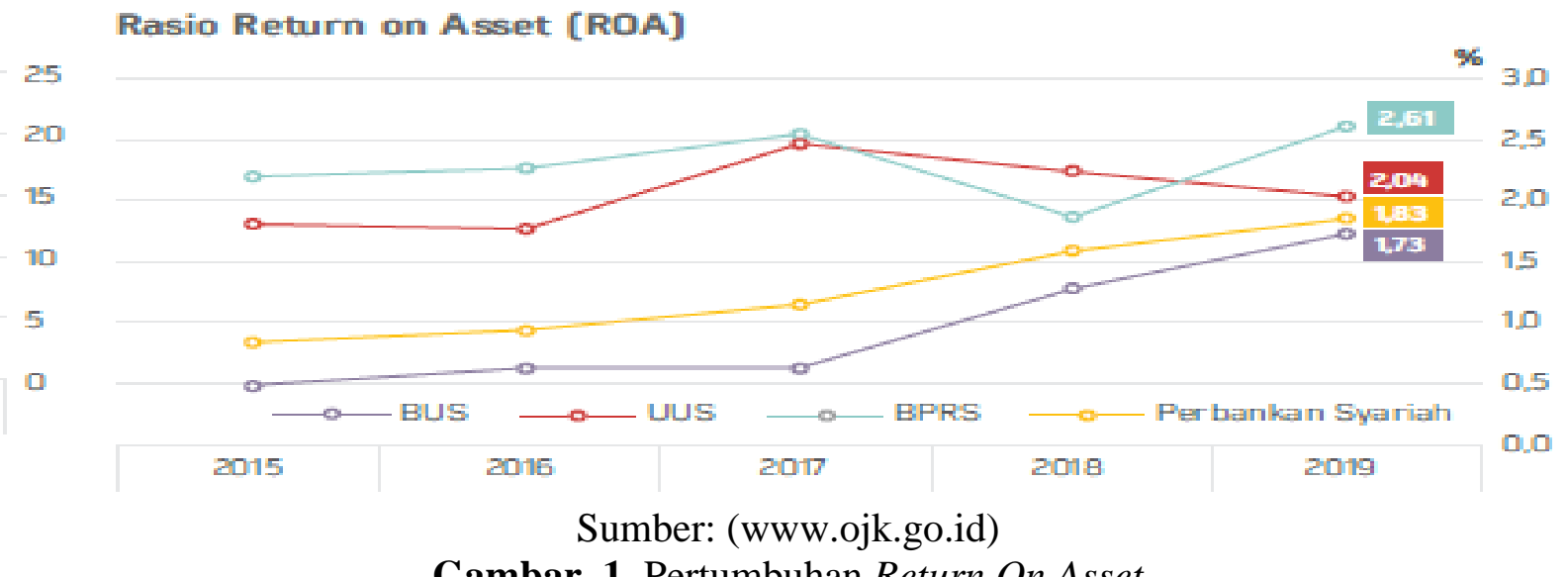

Gambar 1. Pertumbuhan Return On Asset

Gambar 1 diatas dapat menjelaskan tingkat ROA pada bank umum syariah mengalami kenaikan tiap tahunnya kecuali pada 2017 mengalami penurunan, meskipun mengalami penurunan pada 2017, nilai ROA sampai 2019 terus meningkat. Dengan begitu profitabilitas bank umum syariah dapat dikatakan membaik karena hal tersebut tercermin dari nilai ROA pada tahun 2019 sebesar 1,73\%, meningkat cukup signifikan dari 2018 yang sebesar 1,28\%. Hal tersebut membuktikan bahwa bank umum syariah sudah cukup baik dalam memperoleh laba bersihnya dari pengelolaan aset yang dimiliki.

Mengumpulkan dana masyarakat yang disalurkan melalui pembiayaan kepada pihak yang memerlukan untuk mensejahterakan masyarakat menjadi salah satu fungsi dari bank syariah. Dimana produk pembiayaan ini membuatnya menjadi satu dari sekian produk bank syariah yang dapat memperoleh keuntungan. Menurut Rivalah dalam (Widianengsih dkk, 2020) banyaknya total pembiayaan yang tersalurkan kepada masyarakat mampu menentukan keuntungan yang akan didapatkan bank syariah.
Banyaknya keuntungan yang diterima atas pembiayaan yang dapat disalurkan akan menentukan banyaknya pendapatan pada bank umum syariah. Penyaluran dananya dikategorikan berdasarkan beberapa jenis akad yang digunakan, yaitu pembiayaan berdasarkan bagi hasil (akad mudharabah dan akad musyarakah), dengan jual beli (akad murabahah, akad salam,dan akad istisna) dan sewa-menyewa ( akad ijarah dan akad ijarah muntahiyah bitamlik atau IMBT).(OJK, 2017).

Oleh karena itu, bisa dikatakan aktivitas pembiayaan pada bank syariah ini dapat mempengaruhi profitabilitas dari bank syariah. Produk pembiayaan akan penelitigunakan dalam penelitian ini ialah murabahah, musyarakah, dan mudharabah. Karena ketiga pembiayaan tersebut adalah pembiayaan yang menjadi primadona di bank syariah. Hal tersebut dapat tergambar dari data laporan perkembangan keuangan syariah tahun 2019, tercatat pembiayaan dengan akad murabahah paling mendominasi sebesar Rp 168,11 triliun ,disusul oleh pembiayaan musyarakah, dan mudharabah masing-masing sebesar Rp 158,61 triliun dan Rp 14,02 triliun. 


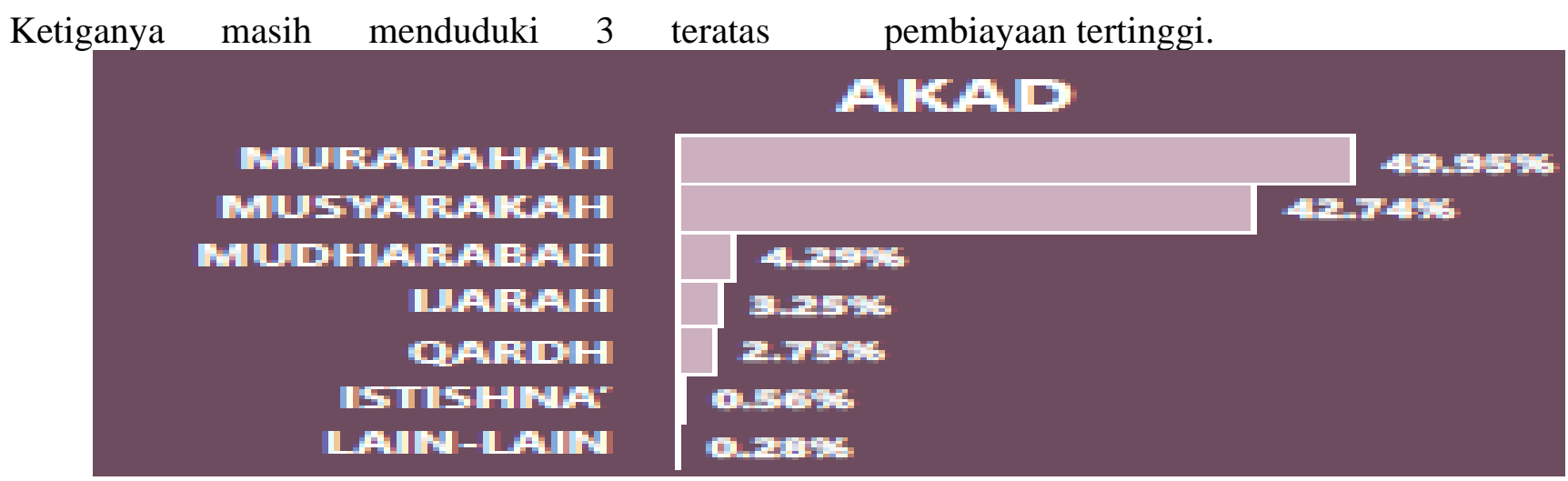

Sumber: (www.ojk.go.id)

Gambar 2. Persentase pembiayaan berdasarkan akad

Berdasarkan gambar 1 diatas yang diambil dari snapshot perbankan syariah tahun 2019 pada situs OJK dapat dilihat produk pembiayaan yang paling banyak disalurkan 49,95\% menggunakan akad Murabahah. Kemudian diikuti oleh produk pembiayaan dengan akad Musyarakah dan Mudharabah, dimana kontribusi akad tersebut dalam pembiayaan masing-masing sebesar $42,74 \%$ dan $4,29 \%$. Jenis pembiayaan baik dengan prinsip jual beli ataupun pembiayaan lainnya dapat sangat berdampak pada profitabilitas yang diperoleh oleh bank syariah (Septiani, 2017).

\section{KAJIAN PUSTAKA PENGEMBANGAN HIPOTESIS}

DAN

\section{Bank Syariah}

UU No 21 tahun 2008 mendefinisikan bahwa "Bank Syariah ialah Bank yang aktivitasnya di dasarkan pada prinsip syariah."

"Bank Syariah ialah lembaga keuangan yang mana aktivitas utamanya menyalurkan jasa pembiayaan dan lainnya dalam laju pembayaran yang berdasarkan pada prinsip syariah islam" (Arwani, 2016:75).

\section{Pembiayaan Murabahah}

Berdasarkan PSAK 102 Akuntansi Murabahah ialah akad jual beli barang yang dalam pelaksanaannya penjual diharuskan mengungkapkan biaya perolehan awal barang tersebut sebelum barang dijual sejumlah biaya perolehan ditambah dengan keuntungan sesuai kesepakatan."

Pembiayaan Murabahah ialah akad pembiayaan dana dimana pihak LKS maupun Bank Syariah sebagai penjual, kemudian menjualnya kepada nasabah dengan mengungkapkan harga beli diawal yang kemudian nasabah akan membeli barang tersebut dengan harga awal yang ditambah dengan keuntungan yang akan didapat pemilik modal berdasarkan kesepakatan bersama (Muljono, 2014:144).

Dalam Fatwa DSN No 04/DSNMUI/IX/2000, "Murabahah ialah bentuk akad jual beli barang dengan pendapatan terdiri dari harga jual awal ditambah keuntungan berdasarkan persetujuan pembeli."

Keuntungan yang diperoleh oleh bank syariah berupa marjin yang di sepakati oleh keduanya, dimana dalam proses akad ini bank syariah selaku penjual harus transfaran terhadap harga pokok barang yang dibeli kepada nasabah sebagai pembeli (Zuhri, 2015:76).

\section{Pembiayaan Musyarakah}

Menurut PSAK 106 paragraf 04 dijelaskan bahwa Musyarakah ialah bentuk kesepakatan dua pihak atau lebih guna sebuah bisnis yang mana tiap pihak memberikan proporsi dana berdasarkan ketentuan keuntungan dibagi bersadarkan kesepakatan, sedangkan kerugian didasarkan pada proporsi dana diawal."

Menurut (Arwani, 2016:90) "landasan terjadinya transaksi musyarakah ini ialah atas munculnya kemauan para pihak yang bersepakat 
dalam meningkatkan nilai aset yang dimilikinya secara bersama-sama merupakan landasaran terjadi transaksi musyarakah ini."

\section{Pembiayaan Mudharabah}

Dalam Fatwa DSN No 07/DSNMUI/IV/200 "Pembiayaan Mudharabah ialah bentuk kesepakatan yang dimana keuntungan usaha dibagi kepada pihak yang menyediakan dana dan pengelola usaha sesuai dengan kesepakatan."

Menurut (Arwani, 2016:92) "Mudharabah ialah jenis kerjasama diantara dua atau lebih pihak yang mana akad ini menekankan bentuk kesepakatan dengan proporsi modal sepenuhnya dari shabhibul maal dan keahlian yang dimiliki mudharib serta pembagian keuntungan yang didapat didasarkan pada perjanjian antara kedua pihak."

\section{Profitabilitas (ROA)}

Dalam menilai kinerja keuangan suatu bank cara yang dapat mengetahuinya ialah dengan melihat profitabilitasnya, dimana profitabilitas ini dapat menjelaskan keberhasilan bank dalam memperoleh keuntungan. Bentuk analisis yang dapat dipergunakan untuk menilai kinerja tersebut ialah rasio keuangan. Hal ini dapat dilakukan dengan melihat rasio profitabilitasnya, menurut (Kasmir, 2015:234) "Profitabilitas dipergunakan untuk menilai tingkat keberhasilan usaha dan kesanggupan emiten mencapai keuntungan."

Salah satu rasio profitabilitas yang dapat diukur dalam menilai kinerja suatu bank ialah Return On Asset. ROA dijadikan untuk mendefinisikan tingkat profitabilitas yang diperoleh bank syariah. "ROA ialah alat yang dipergunakan untuk menggambarkan kemapuan manajemen dalam memperoleh laba bersih dari pengelolaan aset. Posisi bank dalam segi penggunaan aset dikatakan semakin baik apabila nilai ROA pada suatu bank tersebut tinggi, yang dimana dengan semakin tingginya ROA maka tingkat keuntungan yang didapat bank juga semakin tinggi." (Kasmir, 2015:236).

\section{Pengaruh Murabahah terhadap ROA}

Pembiayaan Murabahah adalah produk bank syariah dengan prinsip jual beli. Dalam kegiatannya, pembiayaan ini mendominasi produk pembiayaan pada bank syariah. Transaksi dari akad ini dilaksanakan dengan cara bank membeli barang berdasarkan spesifikasi yang diinginkan nasabah. Selanjutnya, barang akan dijual kepada nasabah dengan keuntungan yang didapat yaitu berupa penambahan harga beli sesuai kesepakatan diantara keduanya.

Jika penyaluran dana murabahah dalam jumlah besar berjalan dengan lancar dalam pengembaliannya, maka pembiayaan murabahah akan memberikan hasil yang menguntungkan bagi bank. Dengan demikian maka laba yang akan didapat oleh bank akan meningkat yang nantinya kan meningkatkan pula profitabilitas pada bank tersebut.

Jadi bisa dikatakan murabahah dapat mempengaruhi tingkat profitabilitas bank. Teori ini sejalan dengan penelitian terdahulu (Widianengsih dkk, 2020) dan (Faradilla dkk, 2017) dengan hasilnya yaitu murabahah berpengaruh terhadap ROA. Tetapi penelitian lain oleh (Kusuma, 2019) murabahah tidak berpengaruh terhadap ROA. Dari pembahasan tersebut peneliti akan mengajukan hipotesis berikut:

H1 : Pembiayaan Murabahah berpengaruh terhadap Profitabilitas (ROA) pada Bank Umum Syariah di Indonesia

\section{Pengaruh Musyarakah terhadap ROA}

Pembiayaan Musyarakah ialah bentuk kesepakatan bersama diantara pemilik modal dalam penyertaan modalnya pada sebuah bisnis, dimana pihak-pihak tersebut mempunyai kontribusi didalam pelaksanaan manajemen bisnis tersebut, dimana keuntungan yang akan diperoleh atas proporsi penyertaan modal ataupun diantara kesepakatan bersama (Yudiana \& Fitria, 2014:49).

Pendapatan yang diterima bank atas pembiayaan ini adalah pendapatan bagi hasil, dengan meningkatnya pembiayaan ini maka aka berdampak pada penambahan keuntungan diterima oleh bank, yang kemudian akan berpengaruh pada kenaikan profitabilitas. 
Jadi bisa dikatakan musyarakah dapat mempengaruhi tingkat profitabilitas bank. Teori ini sejalan dengan penelitian terdahulu (Faradilla dkk, 2017) dan (Nawawi dkk, 2018) dengan hasilnya musyarakah berpengaruh signifikan terhadap ROA. Tetapi penelitian lain oleh (Kusuma, 2019) menyatakan musyarakah tidak berpengaruh terhadap ROA. Dari pembahasan tersebut peneliti akan mengajukan hipotesis berikut:

H2 : Pembiayaan Musyarakah berpengaruh terhadap Profitabilitas (ROA) pada Bank Umum Syariah di Indonesia

\section{Pengaruh Mudharabah terhadap ROA}

Pembiayaan Mudharabah ialah bentuk kesepakatan bersama antara pihak pemilik dana dengan pengelola dana, dimana kerjasama tersebut dilakukan untuk melakukan sebuah usaha yang apabila nantinya usaha yang dijalankan mengalami keuntungan maka hasilnya dibagi berdasarkan kesepakatan bersama, tetapi apabila merugi maka akan ditanggung sepenuhnya oleh pemilik dana.

Pembiayaan Mudharabah ini melibatkan para pengusaha secara langsung. Yang kemudian akan berdampak pada semakin pengajuan pembiayaan ini di bank syariah oleh para pelaku usaha. Dengan demikian pendapatan yang akan diterima bank akan meningkat, karena adanya peningkatan pendapatan dari bagi hasil atas pembiayaan tersebut, dengan kata lain maka laba pada perusahaan juga akan meningkat yang nantinya akan meningkatkan juga profitabilitas pada bank tersebut.

Jadi bisa dikatakan pembiayaan mudharabah akan mempengaruhi tingkat profitabilitas pada bank. Teori ini sejalan dengan penelitian terdahulu (Sari, 2015) dan (Nawawi $\mathrm{dkk}$, 2018) dengan hasilnya mudharabah berpengaruh signifikan terhadap ROA. Tetapi penelitian lain oleh (Faradilla dkk, 2017) menyatakan mudharabah tidak berpengaruh terhadap ROA. Dari pembahasan tersebut peneliti akan mengajukan hipotesis berikut:

H3 : Pembiayaan Mudharabah berpengaruh terhadap Profitabilitas (ROA) pada Bank Umum Syariah di Indonesia.

\section{METODOLOGI PENELITIAN Populasi dan Sampel}

Populasinya ialah seluruh bank umum syariah yang terdaftar di OJK dari tahun 20152019, berjumlah 14 Bank Umum Syariah (BUS). Sampel sebanyak 40 data, terdiri atas 8 BUS dalam rentang 5 tahun penelitian. Sampel didapat dengan teknik purposive sampling dengan kriteria berikut ini: (1) BUS yang terdaftar di OJK sampai tahun 2019, (2) BUS yang menerbitkan laporan keuangan tahunan selama periode 2015-2019, (3) BUS yang mempunyai data variabel lengkap sesuai yang diteliti. Teknik analisis data yang dipakai ialah analisis regresi berganda, pengujian hipotesis dengan (uji-t) dan (uji-F) serta koefisien determinasi.

\section{HASIL DAN PEMBAHASAN Analisis Statistik Deskriptif}

Nilai dari variabel pembiayaan dan ROA diolah kemudian menghasilkan analisis deskriptif sebagai berikut :

Tabel 1. Hasil Analisis Deskriptif

\begin{tabular}{l|c|c|c|c|c}
\hline & $\mathrm{N}$ & Min & Max & Mean & Std. Dev \\
\hline ROA & 40 & $-8,09$ & 1,82 &, 1095 & 1,86022 \\
\hline Murabahah & 40 & 26,11 & 31,32 & 29,1934 & 1,55199 \\
\hline Musyarakah & 40 & 27,18 & 30,89 & 28,9034 & 1,17651 \\
\hline Mudharabah & 40 & 22,23 & 28,84 & 26,6430 & 1,46882 \\
\hline Valid N (listwise) & 40 & & & & \\
\hline
\end{tabular}

Sumber: Olahan Penulis, 2021

Berdasarkan hasil uji diatas, dapat diketahui jumlah data sebanyak 40, yang berasal dari laporan keuangan tahunan BUS periode 20152019. Berdasarkan tabel 1 diatas, maka dapat 
dijelaskan sebagai berikut:

ROA pada hasil pengolahan tersebut dapat diketahui bahwa pada ROA memiliki nilai minimum -8,09; nilai maximum1,82; average sebesar 0,1095; dan standar deviasi 1,86022. Lalu, Pembiayaan Murabahah pada hasil pengolahan tersebut dapat diketahui memiliki nilai terendah sebesar 26,11; nilai tertinggi 31,32 ; rata-rata 29,1934; dan standar deviasi 1,55199. Lalu, Pembiayaan Musyarakah pada hasil pengolahan tersebut dapat diketahui memiliki nilai terendah 27,18 ; nilai tertinggi 30,89 , ratarata 28,9034; dan standar deviasi 1,17651. Selanjutnya, Pembiayaan Mudharabah pada hasil pengolahaan tersebut dapat diketahui memiliki nilai terendah 22,23 ; nilai tertinggi 28,84 ; ratarata 26,6430, dan standar deviasi 1,46882 .

\section{Uji Asumsi Klasik}

Uji Normalitas

Tabel 2. Hasil Uji Normalitas

\begin{tabular}{l|l|r}
\hline \multicolumn{2}{|c|}{} & $\begin{array}{r}\text { Unstandardized } \\
\text { Residual }\end{array}$ \\
\hline $\mathrm{N}$ & Mean & 40 \\
\cline { 2 - 3 } $\begin{array}{l}\text { Normal } \\
\text { Parameters }\end{array}$ & Std. Dev & 1,490099000 \\
\hline \multirow{2}{*}{$\begin{array}{l}\text { Most Extreme } \\
\text { Differences }\end{array}$} & Absolute &, 125 \\
\cline { 2 - 3 } & Positive &, 084 \\
\cline { 2 - 3 } & Negative &,- 125 \\
\hline \multicolumn{2}{|l|}{ Test Statistic } &, 125 \\
\hline \multicolumn{2}{|l|}{ Asymp. Sig. (2-tailed) } &, 113 \\
\hline
\end{tabular}

Sumber: Olahan Penulis, 2021

Dari hasil uji tersebut didapatkan output sebagai berikut : nilai signifikansi $0,113>0,05$ maka dapat dikatakan data berdistribusi normal.
Data dikatakan tidak terjadi multikoliniaritas apabila tolerance $>0,100$ dan VIF < 10,00." (Ghozali, 2011:107-108).

Uji Multikoliniaritas

Tabel 3. Hasil Uji Multikolinieritas

\begin{tabular}{l|l|l|l}
\hline \multicolumn{2}{l|}{ Model } & \multicolumn{2}{l}{ Collinearity Statistics } \\
\cline { 3 - 4 } \multicolumn{2}{l|}{} & Tolerance & VIF \\
\hline \multirow{4}{*}{1} & $($ Constant $)$ & & \\
\cline { 2 - 4 } & Murabahah &, 122 & 8,174 \\
\cline { 2 - 4 } & Musyarakah &, 319 & 3,134 \\
\cline { 2 - 4 } & Mudharabah &, 169 & 5,917 \\
\hline
\end{tabular}

Sumber: Olahan Penulis, 2021

Dari tabel 3 bisa dilihat, dengan bantuan software SPSS v.26 diperoleh output nilai tolerance masing-masing variabel 0,$122 ; 0,319$; dan $0,169>0,100$ dan VIF masing-masing variabel 8,$174 ; 3,134$; dan 5,917 > 10,00. Maka bisa disimpulkan bahwa data tersebut terbebas dari multikolinieritas.

Uji Autokorelasi

Penelitian ini mendeteksi autokorelasi dengan Durbin Watson (DW) dengan nilai DW 1,499 berada diantara -2 dan 2 yang artinya 
Nia Mirandha Septiani \& Wirman/ Pengaruh Pembiayaan Murabahah, Musyarakah, Dan Mudharabah Terhadap Profitabilitas (Roa) Bank Umum Syariah Di Indonesia

penelitian terbebas dari autokorelasi.

Uji Heteroskedastisitas

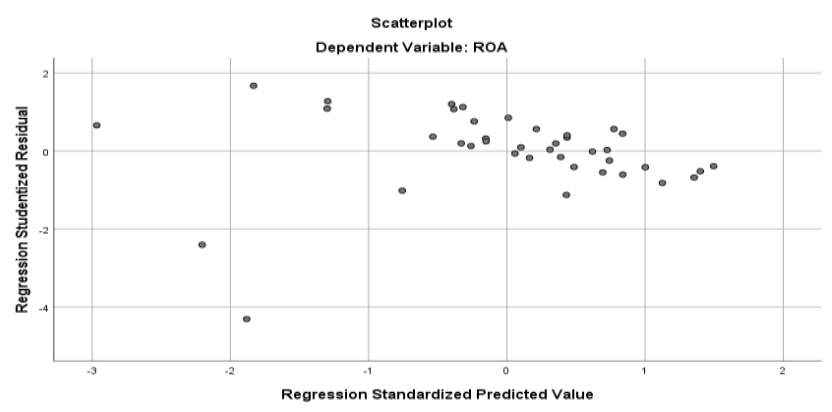

Sumber: Olahan Penulis, 2021

Gambar 2. Hasil Uji Heteroskadastisitas dengan scaterplott

Penelitian ini terbebas dari gejala heteroskedastisitas karena titik-titik tersebut tersebar dan tidak membentuk pola.

\section{Koefisen Determinasi}

Koefisien Determinasi $\left(\boldsymbol{R}^{\mathbf{2}}\right)$ ditujukan untuk melihat sejauh apa tingkat hubungan diantara variabel terikat dengan bebasnya, berikut hasil ujinya:

Tabel 4. Hasil Uji Koefisien Determinasi

\begin{tabular}{c|c|c|c|c|c}
\hline Model & $\mathrm{R}$ & $\begin{array}{c}\mathrm{R} \\
\text { Square }\end{array}$ & $\begin{array}{c}\text { Adjusted } \\
\mathrm{R} \text { Square }\end{array}$ & $\begin{array}{c}\text { Std. Error of } \\
\text { the Estimate }\end{array}$ & $\begin{array}{c}\text { Durbin- } \\
\text { Watson }\end{array}$ \\
\hline 1 &, $592^{\mathrm{a}}$ &, 351 &, 297 & 1,56021 & 1,499 \\
\hline
\end{tabular}

Sumber: Olahan Penulis, 2021

Berdasarkan hasil diatas diperoleh $\left(\boldsymbol{R}^{\mathbf{2}}\right)$ sebesar 0,297 yang dapat diartikan kontribusi dari variabel murabahah, musyarakah, mudharabah mempengaruhi ROA sebesar 30\% sedangkan sisanya $70 \%$ dipengaruhi variabel lain yang tidak diteliti.

\section{Uji F}

Jika nilai Fhitung > Ftabel dikatakan bahwa variabel $(\mathrm{X})$ terhadap variabel $(\mathrm{Y})$ berpengaruh secara simultan (Sujarweni, 2014:155). Tabel distribusi f dicari pada signifikasi 0,05 df1=k (3) dan df2=n-k $(40-3=37)$ hasil perolehan untuk tabel f (3:37) diperoleh Ftabel sebesar 2,86. Berikut hasil pengujian uji $\mathrm{F}$ :

Tabel 5. Hasil Uji Simultan (Uji t)

\begin{tabular}{l|l|l|l|l|c|c}
\hline \multicolumn{7}{l|}{ ANOVA $^{\text {a }}$} \\
\multicolumn{2}{l|}{ Model } & $\begin{array}{l}\text { Sum of } \\
\text { Squares }\end{array}$ & df & $\begin{array}{l}\text { Mean } \\
\text { Square }\end{array}$ & F & Sig. \\
\hline \multirow{2}{l}{1} & Regression & 47,324 & 3 & 15,775 & 6,480 &, $001^{\text {b }}$ \\
\cline { 2 - 7 } & Residual & 87,633 & 36 & 2,434 & & \\
\cline { 2 - 7 } & Total & 134,957 & 39 & & & \\
\hline
\end{tabular}

Sumber: Olahan Penulis, 2021 
Dari hasil tersebut, dapat dilihat nilai Fhitung sebesar 6,480> Ftabel 2,86, dengan tingkat signifikan $0,001<0,005$ maka $H_{0}$ ditolak dan $\mathrm{H}_{4}$ diterima, dengan demikian bahwa model yang digunakan dalam penelitian ini adalah layak.

\section{Uji Hipotesis Secara Parsial (Uji t)}

Uji ini dipergunakan untuk melihat signifikansi dari variabel $\mathrm{X}$ mempengaruhi variabel Y secara parsial. Menurut (Ghozali,
2011:101) "Jika signifikasi $<0,05$ dikatakan bahwa tidak adanya pengaruh variabel (X) terhadap variabel (Y) secara parsial. Jika nilai thitung > ttabel dikatakan bahwa variabel (X) mempunyai pengaruh tehadap variabel (Y) secara parsial (Sujarweni, 2014:155).

Tabel $t$ dicari pada $0,05 / 2=0,025$ dengan $\mathrm{df}=\mathrm{n}-\mathrm{k}-1$ atau $40-3-1=36$. Dengan pengujian 2 sisi (0,025:36) diperoleh tabel sebesar 2,028. Berikut hasil pengujiannya :

Tabel 6. Hasil Uji Parsial Coefficients ${ }^{\mathbf{a}}$

\begin{tabular}{|c|c|c|c|c|c|c|c|c|}
\hline \multirow{2}{*}{\multicolumn{2}{|c|}{ Model }} & \multirow{2}{*}{\begin{tabular}{|l|}
$\begin{array}{l}\text { Unstandardized } \\
\text { Coefficients }\end{array}$ \\
B \\
\end{tabular}} & \multirow{2}{*}{$\begin{array}{l}\begin{array}{l}\text { Standardized } \\
\text { Coefficients }\end{array} \\
\text { Std. Error } \\
\end{array}$} & \multirow{2}{*}{$\begin{array}{l}\begin{array}{l}\text { Unstandardized } \\
\text { Coefficients }\end{array} \\
\text { B } \\
\end{array}$} & \multirow[t]{2}{*}{$\bar{T}$} & \multirow[t]{2}{*}{ Sig. } & \multicolumn{2}{|c|}{$\begin{array}{l}\text { Collinearity } \\
\text { Statistics }\end{array}$} \\
\hline & & & & & & & Tolerance & VIF \\
\hline \multirow[t]{4}{*}{1} & $-21,405$ & 6,214 & $-21,405$ & 6,214 & $-3,445$ & ,001 & & \\
\hline & $-1,385$ & ,460 & $-1,385$ & ,460 & $-3,009$ & ,005 & ,122 & 8,174 \\
\hline & 1,005 & ,376 & 1,005 & ,376 & 2,672 & ,011 & ,319 & 3,134 \\
\hline & 1,235 & ,414 & 1,235 & ,414 & 2,986 & ,005 & , 169 & 5,917 \\
\hline
\end{tabular}

a. Dependent Variable: ROA

Sumber: Olahan Penulis, 2021

\section{Pembiayaan Murabahah berpengaruh terhadap Profitabilitas (ROA) pada Bank Umum Syariah di Indonesia}

Murabahah sebesar -1.385 diartikan bahwa setiap penaikan murabahah sebesar 1, akan menyebabkan turunnya ROA sebesar 1.385 dengan anggapan variabel lainnya tetap. Dari hasil tabel 6 dapat diketahui murabahah (X1) mempunyai pengaruh terhadap ROA. Ditunjukkan oleh -thitung $(-3,009)>$-ttabel (2,028), yang artinya $\boldsymbol{H}_{\mathbf{0}}$ ditolak dan $\boldsymbol{H}_{\mathbf{1}}$ diterima dengan signifikansi $0,005<0,05$, artinya murabahah mempunyai pengaruh negatif signifikan terhadap ROA. Hasil ini sejalan dengan penelitian (Sari, 2015) dimana pembiayaan murabahah berpengaruh negatif terhadap ROA. Hal tersebut dikarenakan terdapat penurunan yang besar atas kewajiban murabahah jika dibandingkan dengan pembiayaan murabahah yang baru dibentuk sehingga mengakibatkan pada penurunan profitabilitas.

\section{Pembiayaan Musyarakah berpengaruh terhadap Profitabilitas (ROA) pada Bank Umum Syariah di Indonesia}

Musyarakah sebesar 1.005 diartikan bahwa setiap penaikan musyarakah sebesar 1, akan menyebabkan naiknya ROA sebesar 1.005 dengan anggapan variabel lain tetap. Dari hasil tabel 6 dapat diketahui musyarakah (X2) mempunyai pengaruh terhadap ROA. Ditunjukkan thitung $(2,672)>$ ttabel $(2,028)$, yang artinya $H_{0}$ ditolak dan $H_{1}$ diterima dengan signifikansi $0,011<0,05$, artinya musyarakah mempunyai pengaruh positifif signifikan terhadap ROA. Hasil ini sejalan dengan penelitian (Prasetyo, 2018) dimana pembiayaan musyarakah berpengaruh positifif signifikan terhadap ROA. Hal ini dikarenakan penyertaan modal dan penanggungan risiko kerugian dibagi oleh masing-masing pihak yang menyebabkan pembiayaan musyarakah mempunyai risiko yang lebih kecil. Hal inilah yang menyebabkan musyarakah mempunyai pengaruh positif terhadap ROA. 


\section{Pembiayaan Mudharabah berpengaruh terhadap Profitabilitas (ROA) pada Bank Umum Syariah di Indonesia.}

Mudharabah sebesar 1.235 diartikan bahwa setiap penaikan mudharabah sebesar 1, akan menyebabkan naiknya ROA sebesar 1.235 dengan anggapan variabel lain tetap. Dari hasil tabel 6 dapat diketahui mudharabah (X3) mempunyai pengaruh terhadap ROA. Ditunjukkan dengan thitung $(2,986)>$ ttabel $(2,028)$, yang artinya $H_{0}$ ditolak dan $H_{1}$ diterima dengan signifikansi $0,005<0,05$, artinya musyarakah mempunyai pengaruh positifif signifikan terhadap ROA. Hasil ini sejalan dengan penelitian (Nawawi dkk, 2018) dimana pembiayaan musyarakah berpengaruh positifif signifikan terhadap ROA. Hal tersebut menandakan semakin besar mudharabah akan diikuti pula pada besarnya profitabilitas yang didapat.

Bentuk pembiayaan ini menegaskan kerjasama dengan proporsi modal sepenuhnya dari shahibul maal. oleh sebab itu pihak bank akan menerima keuntungan yang lebih besar tetapi dengan risiko yang ditanggung juga besar apabila bisnis tersebut merugi.

\section{KESIMPULAN}

Dengan didasarkan pada hasil penelitian telah jelaskan diatas, penulis bisa menyimpulkan: (1) Secara parsial murabahah berpengaruh negatif signifikan terhadap ROA. Hal ini menjelaskan bahwa jika murabahah menurun akan diikuti oleh kenaikan ROA; (2) Secara parsial musyarakah berpengaruh positif signifikan terhadap ROA. Hal ini menunjukkan bahwa jika musyarakah mengalami kenaikan akan sejalan dengan kenaikan ROA; (3) Secara parsial mudharabah berpengaruh positif signifikan terhadap ROA. Hal ini menunjukkan bahwa kenaikan mudharabah akan sejalan dengan kenaikan ROA; (4) secara simultan murabahah, musyarakah, dan mudharabah berpengaruh terhadap ROA pada BUS di Indonesia.

Dari hasil penelitian, pembahasan, serta kesimpulan yang dijelaskan sebelumnya, penulis akan memberikan beberapa saran diantaranya: (1) Bagi BUS diharapkan untuk tetap meningkatkan penyaluran produk pembiayaan musyarakah dan mudharabah karena akan berpengaruh terhadap ROA bank tersebut; (2) Bank Umum Syariah sebaiknya dapat menyelaraskan didalam penyaluran pembiayaan murabahah antara percepatan piutang dengan pembentukan biaya baru, sehingga hal tersebut dapat berpengaruh pada pelusanan pembiayaan disetiap bulannya yang agar tidak berdampak negatif pada ROA; (3) Bagi peneliti selanjutnya, penulis mengharapkan untuk bisa menambah variabel bebas lain, selain dari variabel yang telah digunakan penulis, sehingga hasil dari penelitian akan lebih mendalam, dan bisa menjadi bahan perbandingan dengan hasil penelitian penulis.

\section{DAFTAR PUSTAKA}

Arwani, A. (2016). Akuntansi Perbankan Syariah dari Teori ke Praktik (Adopsi IFRS). Yogyakarta: Deepublish .

Dirvi, D. S. A., Eksandy, A., \& Mulyadi, M. (2020). Pengaruh Growth Opportunity, Nwc, Cash Conversion Cycle, Ios Dan Leverage Terhadap Cash Holding. Jemasi: Jurnal Ekonomi Manajemen Dan Akuntansi, 16(1), 44-58.

Ghozali, I. (2011). Aplikasi Analisis Multivariate dengan Program IBM SPSS 19. Semarang: Badan Penerbit Undip.

Kasmir. (2015). Analisa Laporan Keuangan . Jakarta: Rajawali Pers.

Muljono, D. (2014). Buku Pintar Akuntansi Perbankan dan Lembaga Keuangan Syariah. Yogyakarta: ANDI .

Sujarweni, V. (2014). SPSS untuk Penelitian . Yogyakarta: Pustaka baru Press.

Yudiana, \& Fitria, E. (2014). Manajemen Pembiayaan Bank Syariah. Salatiga: STAIN Salatiga Press.

Zuhri. (2015). Akuntansi Penghimpun Dana Bank Syariah. Yogyakarta: Deepublish.

Faradilla, C., Arfan, M., \& Shabri, M. (2017). 
Nia Mirandha Septiani \& Wirman/ Pengaruh Pembiayaan Murabahah, Musyarakah, Dan Mudharabah Terhadap Profitabilitas (Roa) Bank Umum Syariah Di Indonesia

Pengaruh Pembiayaan Murabahah,Istishna,Ijarah,Mudharabah dan Musyarakah Terhadap Profitabilitas Bank Umum Syariah di Indonesia. Reviu Akuntansi Dan Bisnis Indonesia, 4(1), 1018. https://doi.org/10.18196/rab.040155

Kusuma, R. A. (2019). Pengaruh Pembiayaan Mudharabah, Pembiayaan Musyarakah, Pembiayaan Sewa/Ijarah, dan Pembiayaan Murabahah Terhadap Profitabilitas Bank Muamalat Indonesia (Periode 2012-2018).

Nawawi, A., Nurdiansyah, D. H., \& Al Qodliyah, D. S. A. (2018). Pengaruh Pembiayaan Mudharabah dan Musyarakah Terhadap Profitabilitas (ROA) Pada BPRS HIK Bekasi Kantor Cabang Karawang. FALAH: Jurnal Ekonomi Syariah, 3(2), 96. https://doi.org/10.22219/jes.v3i2.7679

Prasetyo, A. M. (2018). PENGARUH PEMBIAYAAN MUDHARABAH, MUSYARAKAH, MURABAHAH DAN NON PERFORMING FINANCING TERHADAP PROFITABILITAS BANK UMUM SYARIAH PERIODE 2012-2016.

Sari, M. (2015). Pengaruh Pembiayaan Mudharabah, Pembiayaan Musyarakah, dan Pembiayaan Murabahah Terhadap Profitabilitas pada Bank Syariah Mandiri dan Bank Muamalat Indonesia (Studi pada Bank Umum Syariah Yang terdaftar di Bank Indonesia Periode Triwulan I 2007Triwulan. Akunida Issn 2442-3037, 2(1), 43-58.

Septiani, A. (2017). Analisis Pengaruh Pembiayaan Mudharabah, Pembiayaan Musyarakah, dan Pembiayaan Murabahah Terhadap Profitabilitas Bank Umum Syariah yang Terdaftar di Bank Indonesia. Journal of Chemical Information and Modeling, 01(01), 1689-1699.

Widianengsih, N., Diana, N., \& Suartini, S. (2020). Pengaruh Pembiayaan Murabahah , Mudharabah dan Musyarakah Terhadap Tingkat Profitabilitas Bank Syariah di Indonesia. Jurnal AKUNSIKA Akuntansi Dan Keuangan, Universitas Singaperbangsa Karawang, 1(1).
Fatwa Dewan Syariah Nasional No 04/DSNMUI/IX/2000IAS Tentang Murabahah

Fatwa Dewan Syatiah Nasional No 07/DSNMUI/IV/200 Tentang Mudharabah

PSAK 102 Pernyataan Standar Akuntansi Keuangan Murabahah

PSAK 106 Pernyataan Standar Akuntansi Keuangan Musyarakah

UU No 21 tahun 2008

www.bankmuamalat.co.id (diakses tanggal 11 Januari 2021)

www.bankvictoriasyariah.co.id (diakses tanggal 18 Januari 2021)

www.bcasyariah.co.id (diakses tanggal 18 Januari 2021)

www.bjbsyariah.co.id (diakses tanggal 18 Januari 2021)

www.bnisyariah.co.id (diakses tanggal 18 Januari 2021)

www.brisyariah.co.id (diakses tanggal 18 Januari 2021)

www.mandirisyariah.co.id (diakses tanggal 18 Januari 2021)

www.ojk.co.id (diakses tanggal 11 Januari 2021)

www.syariahbukopin.co.id (diakses tanggal 18 Januari 2021) 